\title{
Diabetic Mastopathy and Breast Cancer in Type-2 Diabetes Mellitus Patient: A Case Report
}

\section{Tip 2 Diyabetli Hastada Diyabetik Mastopati ve Meme Kanseri: Olgu Sunumu}

\author{
Onur Can Güler', Melda Bulut ${ }^{2}$, Cihangir Özaslan', Yavuz Selim Kahraman \\ ${ }^{1}$ Department of Surgery, Ankara Oncology Training and Research Hospital, Ankara, Turkey \\ ${ }^{2}$ Department of Pathology, Ankara Oncology Training and Research Hospital, Ankara, Turkey
}

Dergiye Ulaşma Tarihi: 16/01/2016 Dergiye Kabul Tarihi 15/02/2016: Doi: 10.5505/aot.2016.09719

\begin{abstract}
ÖZET
Diyabetik mastopati; lenfositik lobulit, duktit ve stromal fibrozisli perivaskülit tablosuyla karakterize nadir görülen bir fibroinflamatuar meme hastalığıdır. Bu meme lezyonu uzun süreli tip 1 diyabet ve diğer otoimmün hastalıkları olanlarda, genellikle unilateral veya bilateral palpe edilebilir. Memede kitle ile başvuran ve kliniği malign olan diyabetik mastopatili hastayı raporluyoruz. $\mathrm{Bu}$ tip 2 diyabetli hastamız 74 yaşındadır. Mamografisi ve ultrasonografisi malignite şüphesi uyandırdığından bu hastaya tel yardımıyla eksizyonel biyopsi uygulandı. Biyopsi sonucu invaziv karsinom olarak raporland1. Bu biyopsi sonucuyla yapılan operasyon sonrasi patoloji raporunda ise yoğun keloid benzeri stromal fibrozisin eşlik ettiği lenfoid değişimlerin diyabetik mastopati ile uyumlu olduğu bildirildi.
\end{abstract}

Anahtar kelimeler: diyabetik mastopati, memede kitle, lenfositik lobulit

\section{ABSTRACT}

Diabetic mastopathy is a rare inflammatory breast disease demonstrated with ductitis, lymphocytic lobulitis and perivasculitis with stromal fibrosis. This lesion often presents as a discretely palpable uni- or bilateral mass in traditional type I diabetes and other autoimmune diseases. We report a case of diabetic mastopathy, which presented clinically as an indeterminate breast lump suspicious for malignancy. The patient is a 74-year-old woman who had type 2 diabetes mellitus. Mammography and ultrasonography raised a suspicion of malignancy, and a wire-guided excisional biopsy was performed. The biopsy was reported as invasive carcinoma. Histopathological examination now showed dense keloid-like stromal fibrosis with lymphoid features consistent with diabetic mastopathy.

Key words: diabetic mastopathy, breast mass, lymphocytic lobulitis

\section{Introduction}

Diabetic mastopathy (DMP) is a collection of clinical, radiological and histological features found in dense fibrous masses of the breast initially described by Soler and Khardori (1). The disease is associated with long-standing traditional type 1 insulin-dependent diabetes mellitus (IDDM) but has been reported in other autoimmune disorders or rarely in type 2 diabetes mellitus like in our patient. These patients present with a palpable hard, painless, irregular solitary mass in one breast or both. As inconclusive clinical and imaging findings, these lesions are often evaluated as breast carcinomas. A carefully examination of this disease is essential to avoid unnecessary surgical biopsies.

\section{Case Presentation}

The patient described is a 74-year-old female, who presented with a lump in her left breast of 2 months duration. There was no associated pain; she noticed the lump incidentally. She has been treated for type 2 diabetes for the last ten years with oral antidiabetic agent and had no secondary complication of diabetes; also, there was no history of autoimmune diseases,

The examination showed a hard palpable, relatively immobile, painless mass whose location appeared to be deep in the breast tissue. The mass was located $4 \mathrm{~cm}$ lateral 
to the areolar region at 3 o'clock direction of the left breast. Axillary lymph nodes were not palpable, and there was no history of nipple discharge. The right breast examination was normal.

Mammography revealed increased fibro glandular densities in both breasts (type2) with dense mass in the outer quadrant of the left breast. It was thought to be an intramammarian lymph node. There were no micro calcifications detected. Hypoechoic mass which was $4,5 \mathrm{~cm}$ in size, in 3 o'clock direction at the lateral merge of the areolar region of left breast was detected at the location of the focus of micro calcification defined on ultrasonography. According to The Breast Imaging Reporting and Data System (BIRADS) categorization, the lesion was an indeterminate breast lump, and hence, the clinical impression was suspicious for breast carcinoma. Magnetic resonance imaging (MRI) revealed that a $7 \mathrm{~mm}$ sized lesion near the anterior axillary line and it was $12 \mathrm{~cm}$ away from the nipple, oval shaped and well demarcated, contrasted with type 2-3 pattern. MRI reported this lesion as the intramammarian lymph node described in mammography.
A wire-guided excisional biopsy was performed. Gross pathology of the excised specimen was a whitish irregular breast tissue. There was no visible mass lesion in the specimen. In microscopic examination, in an area of $2 \mathrm{~mm}$ in size, a tumor with tubule-like structures, hyperchromatic nuclei and eosinophilic cytoplasm represented the characteristic appearance of an invasive carcinoma(Figure-1). Because of the fractionation of the materials, surgical margins couldn't be detected. Peritumoral tissue consists of fibrosis and chronic inflammation.

In the aspect of this malignant pathology report, breast-conserving surgery and axillary sentinel lymph node biopsy were done on the left breast. The sentinel lymph node was reactive. In postoperative pathological macroscopic examination; a whitish, elastic lesion of $3.5 \mathrm{~cm}$ in diameter with irregular margins was reported. Around the lobules of the breast, mononuclear inflammatory cells, dominant lymphocytic infiltrations were noticed in microscopic details of the postoperative pathology report. These features were pathognomonic for sclerosing lymphocytic lobulitis. (Figure-2) There was no residual carcinoma.

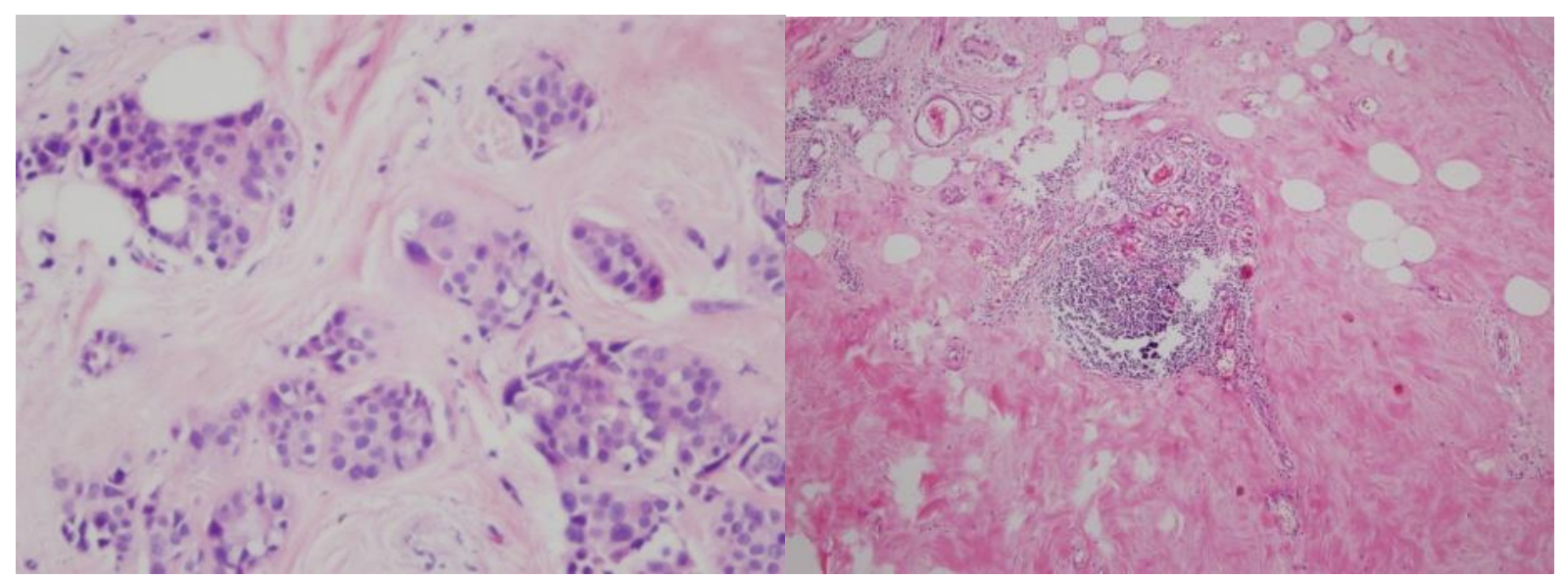

Figure -1: Tubule like structures and groups of neoplastic cells: Invasive carcinoma (HE X 200), 2:

Lymphocytic infiltration around the lobules in the breast stromal tissue; sclerosing lymphocytic lobulitis.

(HEx100)

\section{Discussion}

Diabetic mastopathy (DMP) or sclerosing lymphocytic lobulitis, is a rare, benign tumor like the proliferation of fibrous tissue between lobules. DMP is further characterized by the presence of small lymphocytes in the lobules of the breasts. Recent studies reported that DMP is highly associated with type 1 diabetes mellitus and is often accompanied by other complications of diabetes, especially diabetic retinopathy (1). A few cases of DMP were reported in patients with a long-term history of type 2 diabetes in our patient $(2,3)$. DMP is 
presented classically in premenopausal women, is less common in postmenopausal women, and is rare in men (4). Most reported female patients have been in their 30s; however, the patient presented here was much older and postmenopausal. Common clinical manifestations of DMP include multiple hard, mobile, bilateral, ill-defined, irregular breast lumps. Most patients have complained no pain, but a few have had serious pain (5). Some patients have presented with multiple unilateral lumps (6) or bloody nipple discharge (7).

In the beginning, breast ultrasonography usually demonstrates irregular, ill-defined, clear, hypoechoic shadowed breast nodules. Doppler flow imaging indicates no blood flow signal (8), which would be detected in the case of breast carcinoma. Mammography often shows asymmetric increased-density with disordered glandular structures, and no clear-cut mass or sand-like calcification. It is hard to differentiate DMP from breast cancer by under of mammography alone. The case in the present study had similar ultrasonographic and mammographic presentations compared with those described in other studies. Attitudes towards the effectiveness of breast magnetic resonance imaging (MRI) for the diagnosis of DMP vary (9); however, few individual case reports in the literature have covered the use, they concluded that MRI is not always useful in differentiating these lesions (10). Our patient's MRI was also ineffective, the lesion was reported as an intramammarian lymph node. From a clinical point of view, we recommended breast ultrasonography and mammography. Although the radiologists cannot clearly distinguish DMP from breast cancer, they provided some crucial clinical information and advice guided core needle biopsy or excisional biopsy (11-14).

Core needle biopsy can be performed to avoid unnecessary surgical biopsy as much as possible. In our study, excisional biopsy was performed. For patients with no complaints of discomfort, no further treatment is needed after diagnosis of DMP, but regular follow-up is recommended. Few cases of DMP have developed into breast cancer. A diabetic and kidney transplanted patient with DMP confirmed by excisional biopsy was found to have invasive breast cancer ten years later (15).
Thorncroft et al considered it to be a coincidence as there is no clear pathologic evidence suggesting that breast cancer is associated with DMP (11). Our patient had malignant lesion synchronized with diabetic mastopathy.

DMP is a rare inflammatory disease of the breast that is difficult to identify from breast cancer by clinical manifestations. Regular follow-up is the main treatment. Breast ultrasonography and mammography are recommended. If the lesions become radiologically or clinically suspicious for malignancy core biopsy should be performed. If the core biopsy is inadequate, excisional biopsy is the diagnostic option.

\section{Conflict of interest: None}

\section{References}

1. Soler NG, Khardori R. Fibrous disease of the breast, thyroiditis and cheiroarthropathy in type I diabetes mellitus. Lancet 1984; 1(8370): 193-195.

2.Cirrito D, Orlando AA, Narese F, et al.Diagnostic and therapeutic management of diabetic mastopathy: a case report. Clin Ter. 2015; 166:e169-72.

3. Accurso A, Della Corte GA, et al. Unusual breast lesion mimicking cancer: diabetic mastopathy.Int J Surg. 2014; 12:S79-82.

4. Leroux-Stewart J, Rabasa-Lhoret R. Diabetic mastopathy: case report and summary of literature. Can J Diabetes 2014; 38:305-6.

5. Perret WL, Malara FA, Hill PA, et al. Painful diabetic mastopathy as a reason for mastectomy. Breast $\mathrm{J}$ 2006;12:559-62.

6.Utada Y, Watanabe T, Kajiwara T, Shimizu T, Imamura $\mathrm{H}$, Watanabe $\mathrm{O}$, et al. A case of diabetic mastopathy with multiple lesions mimicking breast cancer. BreastCancer 2003;10:371-3.

7. Wang Z, LeonardMHJr, Khamapirad T, et al. Bilateral extensive ductitis obliterans manifested by bloody nipple discharge in a patient with long-term diabetes mellitus. Breast J 2007;13:599-602.

8.Ricart Selma J, Camps Herrero C, Martínez Rubio R. et al. Diabetic mastopathy: Clinical presentation, imaging and histologic findings, and treatment. Radiología. 2011;53:349-354.

9. Isomoto I, Wada T, Abe K, et al. Diagnostic utility of diffusion-weighted magnetic resonance imaging in diabetic mastopathy. Clin Imaging 2009;33:146-9.

10. Sakuhara Y, Shinozaki T, Hozumi Y, et al. MR imaging in diabetic mastopathy. AJR Am J Roentgenol 2002;179:1201-3.

11. Thorncroft K, Forsyth L, Desmond S, et al. The diagnosis and management of diabetic mastopathy. Breast J 2007;13:607-13.

12. Seidman JD, Schnaper LA, Phillips LE. Mastopathy in insulin-requiring diabetes mellitus. Hum Pathol $1994 ; 25: 819-24$. 
13. Tomaszewski JE, Brooks JS, Hicks D, et al. Diabetic mastopathy: a distinctive clinicopathologic entity. Hum Pathol 1992;23:780-6.

14. Camuto PM, Zetrenne E, Ponn T. Diabetic mastopathy: a report of 5 cases and a review of the literature. Arch Surg 2000;135:1190-3.
15. Mackey SP, Sinha S, Pusey J, et al. Breast carcinoma in diabetic mastopathy. Breast 2005;14:392-8. 